\title{
HOW CAN STEM EDUCATION PROVIDE 'LIGHT-BULB' MOMENTS?
}

\author{
DR LIZ JOHNSON IS A STEM EDUCATION SPECIALIST BASED AT SOUTHERN \\ RESEARCH IN ALABAMA, USA. SHE IMPLEMENTS AN OUTREACH \\ PROGRAMME THAT WORKS TO ENHANCE 6TH-12TH GRADE STEM EDUCATION \\ AND INSPIRE YOUNG PEOPLE TO EMBRACE THE JOY OF ALL THINGS STEM
}

The importance of science, technology, engineering and mathematics (STEM) can hardly be overstated. These areas of research affect our everyday lives in numerous ways, from the smartphones we have, to the houses we live in, from the energy we use, to the medicine we benefit from; none would be possible without STEM. It is vital that teachers and mentors across the world encourage active student participation in STEM - something that Dr Liz Johnson is passionate about.

Based at Southern Research in Alabama, USA, Liz is a STEM education specialist who, along with her colleague Dr Kathryn Lanier, devises STEM outreach activities such as summer learning programmes, field trips, after-school programming and science fairs. The programme targets 6 th-12th grade students (11-18 year olds).

\section{ARE THERE SIMILARITIES AND \\ DIFFERENCES BETWEEN THE \\ DIFFERENT AGE GROUPS?}

$\mathrm{Liz}$ and the team want to expose students to the wonders and excitement of STEM and strengthen their confidence in pursuing STEM careers. They do this by engaging them in activities that will be increasingly relevant as the world becomes ever more STEM-centric. Although the ultimate aim of the programme is the same for all ages, there are differences between middle and high school students. "The STEM content of each programme is designed to align with the standards and curriculum of the participating age groups. For example, in our green engineering field trip series, we use calculus with high school students and algebra with middle school students," explains Liz. "A major similarity between the age groups is their level of excitement when entering our STEM Lab - it looks quite different to a typical school lab. When students enter, they tell us it looks like Disney World or Nickelodeon studios!"
WHAT KIND OF FIELD TRIP

EXPERIENCES ARE PART OF THE PROGRAMME?

Southern Research designs field trips linked to its key research areas of Drug Discovery, Drug Development, Engineering, and Energy \& Environment. For example, through the green engineering series, students explore renewable energy and are challenged to design the most energy efficient wind turbine or solar panel prototype.

Liz describes another field trip focused on the spread of infectious diseases: "Students participate in a simulated disease outbreak and are tasked with collecting data to determine patient zero, while also considering the factors that led to the outbreak. They learn about the primary and secondary immune response and how it relates to vaccines for diseases, and they diagnose disease in patients using enzyme-linked immunosorbent assays (ELISAs)."

HOW DOES THE PROGRAMME HELP STUDENTS TO THINK CRITICALLY AND PROBLEM SOLVE?

A key part of the programme is presenting students with real world problems that need solutions. Relevant background materials and resources are provided but, Liz explains, "Students are challenged to drive the design of the experiment themselves." Collaboration is achieved by having the students work in teams and, quite often, their first efforts are unsuccessful - this requires them to analyse their approach, reassess their strategy and try again.

\section{WHAT DOES LIZ AIM TO ACHIEVE} WHEN SHE VISITS A SCHOOL?

Liz and the team put on STEM shows which involve large-scale experiments designed to engage and inspire students. "Through these experiences, we hope to capture students' attention and encourage them to participate in STEM courses and extra-curricular STEM activities," says Liz. "We also aim to reinforce the concepts students are learning in their lessons through memorable and exhilarating demonstrations."

\section{WHAT HAVE BEEN HIGHLIGHTS OF THE} SUMMER ACADEMIES?

"Last year, we offered a new week-long programme called Drone Academy that introduced high school students to computer aided design (CAD), 3D printing, electrical engineering, and drone technology," enthuses Liz. "A major highlight of this programme was seeing the wide array of creative drone designs students developed in a matter of days, with little to no 3D modelling experience. We had drones that looked like UFOs, the Millennium Falcon from Star Wars, and one that even incorporated chicken feet as landing gear! We also had a special guest, Dr Chris Crawford from the University of Alabama, who shared his research on brain-computer interfaces $(\mathrm{BCl})$ and showed students how to pilot a drone using their brain waves and an electroencephalogram (EEG) sensor!"

As with everything Liz and the team at Southern Research devise, such programmes are about instilling a long-term love of STEM. She adds, "The Drone Academy led some students to pursue internship opportunities, as well as enrol in pilot licence programmes."

The opportunities offered by Southern Research are wide and varied because, as Liz knows, that is the joy of STEM itself. 


\section{MEET THREE STUDENT STEM AMBASSADORS}

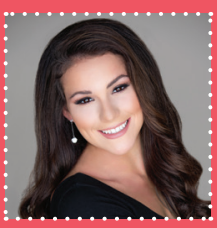

\section{ALEXANDRA AUDIE}

University of Alabama at Birmingham

Majoring in Biomedical Sciences

Minoring in STEM Education

As a high school senior, I was Vice President for the Girls Exploring Math \& Science programme when we presented at the 2019 exposition at Southern Research. I thought it would be amazing to work there. Six months later, I listened to a lecture given by Dr Kathryn Lanier who spoke about openings for STEM ambassadors. A month later, I started as an ambassador!

I assist with stimulating lab experiences for a variety of STEM branches, mentoring students to discover their passions, and having conversations to probe students' interests and understanding. My role involves influencing somebody else's future and that's priceless.

I have gained confidence in my ability to lead others, which has led to my growth as a student and an employee. I have been exposed to new situations and opportunities. Most importantly, I have gotten affirmation that I am doing what I love.

Ultimately, I aim to obtain my Masters in Physician Assistant Studies so I can become a neonatal physician assistant. I would like to practise neonatal medicine and actively participate in diagnostic and neonatal treatment research.

I would tell students considering a future in STEM to find what they are passionate about. Remember, it does not matter what other people think. When you find what you are passionate about, you won't want to settle for anything else.

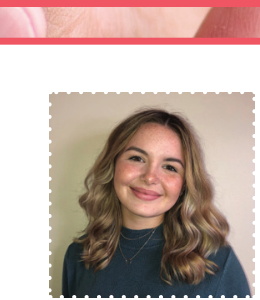

\section{AMBER LAKEY \\ University of Alabama at Birmingham \\ Majoring in Mathematics \\ Minoring in STEM Education}

I heard about the programme when the STEM Education Outreach Director,

Dr Kathryn Lanier, visited a class I attended. She gave a presentation and I fell in love with the programme instantly. I applied, interviewed and was offered the position.

I work with individual students as well as groups. As students experience the lab, I ask critical thinking questions, guide their thought process, and provide instructions for the experiments.

I love that STEM is a collection of separate disciplines that aren't really separate at all! If you study one STEM field, you get to study them all - STEM subjects all rely on each other to work. Being involved in STEM means you're involved in something much bigger and more important than you think.

Working at Southern Research is incredibly rewarding and fun. I get to tell a new group of students how awesome STEM is every time I work! My passion is education and the lab is the perfect place to encourage learning in a way that makes students excited.

I plan on teaching maths at high school level before moving on to school administration. My dream is to run for office and influence educational policy in a way that encourages schools to be more open with students about opportunities and options.

If you are considering studying in STEM, don't ever think that you're done learning. STEM is so exciting; there will always be something new to learn and discoveries to be made!

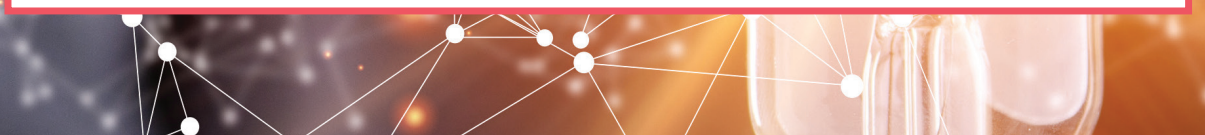

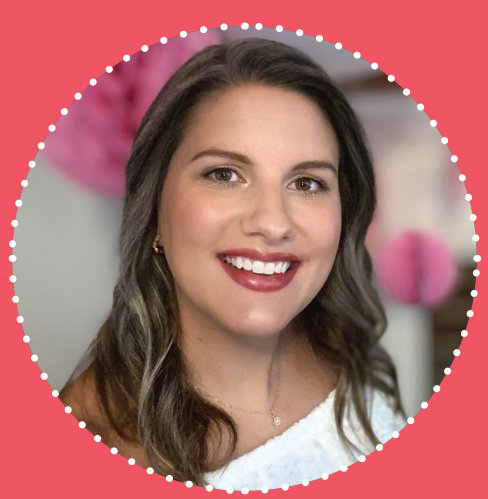

DR IIZ JOHNSON

STEM Education Specialist, Southern Research, Birmingham, Alabama, USA.

\section{FIELD OF RESEARCH}

STEM Education

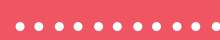

\section{RESEARCH PROJECT}

Liz is part of Southern Research's STEM Education Outreach programme, which enhances 6th-12th grade STEM education by drawing upon the expertise and scholarly contributions of the Southern Research community.

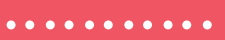

\section{FUNDERS}

The State of Alabama, The Community Foundation of Greater Birmingham, American Honda Foundation, Motorola Solutions Foundation, Best Buy, Wells Fargo, Spire Energy.

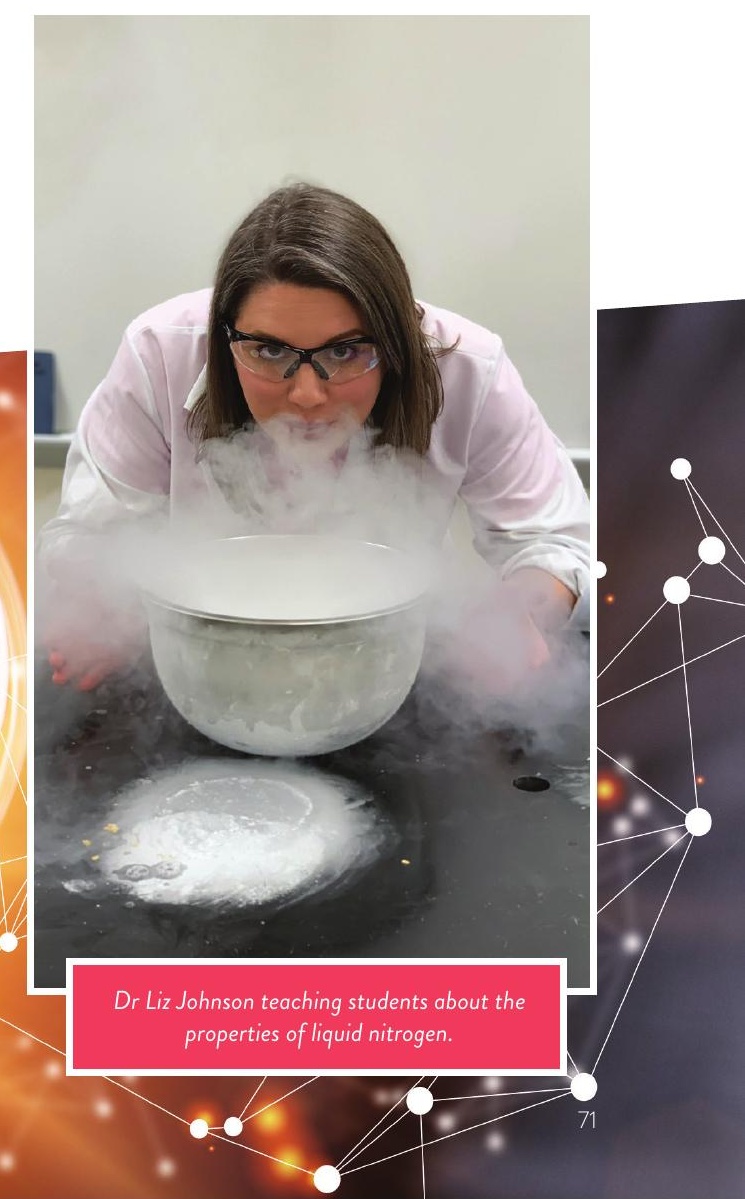




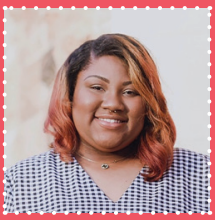

TYHRE HEATH

University of Alabama at

Birmingham

Majoring in Mathematics

Minoring in STEM Education

I was contacted about being a STEM ambassador by UAB Teach, a university programme that helps prepare students to become highly qualified STEM educators. Once I researched what a STEM ambassador actually was, I was eager to get started! It is an amazing programme.

As STEM ambassadors, we work with and guide students through different experiments and lessons. Our ultimate purpose is to make them comfortable enough to use their own critical thinking skills to succeed. Primarily, I like mathematics, but I think STEM prepares you for all realworld applications.

From working on this programme, I have gained more confidence working with middle school aged children, knowledge about science subjects I wasn't familiar with, and a 'family', with Dr Lanier, Dr Johnson and fellow ambassadors. We are encouraged to do well in the programme, to do better in school and to be career ready!

When I graduate, I hope to work in one of the school systems I have seen come through the STEM lab, so I can continue to work closely with Southern Research. As an upcoming teacher, I aim to change students' minds about math - I plan to make maths as enjoyable as possible!

STEM can take you anywhere. If you're not sure if STEM is for you, join a programme like Southern Research's so you can actually see what it's like to be in the field.

\section{PATHWAY FROM SCHOOL TO STEM EDUCATION}

Any number of STEM courses, including chemistry, biology, physics, geology, computer science, engineering and mathematics, can pave the way for a career in STEM education but Liz insists the most important thing is to choose courses you are passionate about. "That passion will not only make the course more enjoyable, it will also make your presentation of the topic more engaging to your audience," explains Liz. "I would also recommend you take a few classes in education if you are able. This can help you develop the techniques and tools to effectively implement STEM activities both in and out of the classroom."

Keep in mind that you do not have to become a scientist or engineer if you study STEM. The beauty of these subjects is that they are integrative and help us make informed, data-driven decisions to solve global issues. "Students with a background in STEM can go on to become financial advisors, data analysts for Disney World, virtual reality game developers, public health officials, project managers for social media organisations, or even CEOs of fortune 500 companies," says Liz
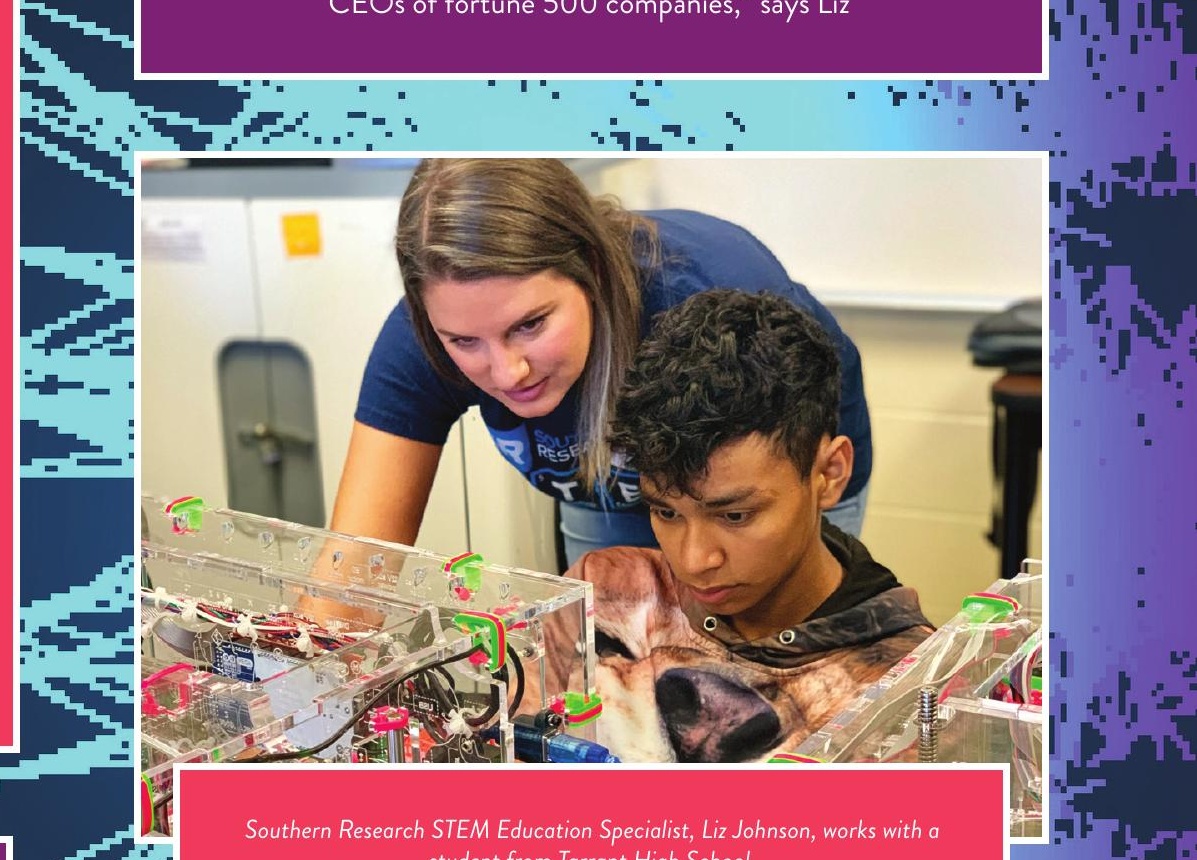

\section{HOW TO BECOME A STEM EDUCATOR}

- Teach.com has an entire section of its site dedicated to helping students realise their ambitions of teaching STEM: https://teach.com/careers/become-a-teacher/ what-can-i-teach/stem/

- STEM Learning is a UK-based enterprise that has a wealth of information regarding achieving a leading STEM education for young people. Wherever you are based, it will give you important context if you are considering a career as a STEM educator: https://www.stem.org.uk/about-us

-100Kin10 is a wonderful organisation with a mission to enrich America's classrooms. The chief aim is to get 100,000 excellent STEM teachers into classrooms by 2021: https://100kin10.org/ 


\section{. HOW DID DR LIZ JOHNSON BECOME A STEM EDUCATOR?}

WHAT WERE YOUR INTERESTS AS A CHILD?

I was a budding ecologist. I loved being outdoors and discovering all the wildlife that lived in the surrounding areas. I often tried to bring creatures home as pets - thankfully, my mother reminded me of the importance of leaving them in their natural habitat! I was also an avid swimmer and spent most of my free time in the water, both competitively and for fun.

WHO OR WHAT HAS INSPIRED YOU IN YOUR CAREER?

I didn't realise I wanted to pursue STEM as a career until I was a senior at the University of Alabama and participated in undergraduate research with Dr Ryan Earley. In his lab, I fell in love with the excitement and freedom of pursuing scientific questions that no one knew the answers to and I loved the collaborative environment. Through my dissertation work with Ryan, I discovered a passion for mentoring undergraduates in the scientific process. Watching students progress from timid lab assistants to individuals designing and driving their own research projects lit a fire within me to pursue STEM education. I wanted to continue to make a positive impact on future generations through engaging students in hands-on, experiential STEM learning and give them the opportunity to experience the addictive 'light bulb moment' when a new idea or concept clicks!

WHAT ATTRIBUTES HAVE ENABLED YOU TO BECOME A SUCCESSFUL SCIENTIST?

Failure, tenacity and collaboration. Whether an experiment doesn't pan out or a grant is denied, failure is an all too common occurrence in the scientific world. Rather than seeing those failures as dead ends, I learned to embrace them as opportunities to try new research techniques or re-evaluate research proposals. When I felt discouraged, I reached out to my lab mates and mentors, and we worked together to develop new ideas, or they offered different perspectives that helped improve my work. These attributes continue to help me be successful in my career in STEM education.
HOW DO YOU OVERCOME OBSTACLES IN YOUR WORK?

I am a strong believer in 'teamwork makes the dreamwork', so I will often seek advice and input from my co-workers, family, or friends. Often, they have come across similar challenges and can provide valuable insights. I have found it very helpful to get together with a group to bounce ideas and solutions around. Two brains are better than one!

\section{WHAT ARE YOUR AMBITIONS?}

My ultimate career goal is to help develop and improve scientific literacy among K-12 students. While not every student will pursue a career in STEM, the critical thinking and problem-solving skills they learn in STEM courses will help them succeed at school and in their career, and it will help them understand and make informed decisions about many of the issues society faces, like climate change, vaccine development, and genetically modified foods.

\section{LIZ'S TOP TIPS}

1. Say yes to almost every opportunity. The best way to figure out what interests you or what you're passionate about is to give it a try. Trying different things can also help illuminate what you don't like. So, join the robotics team, take the elective class on marine biology, participate in a creek clean up, or volunteer at a local hospital!

2. Don't be discouraged by failure. Utilise these opportunities to identify and improve weaknesses in your experimental design or understanding of a topic. If you feel stuck, don't be afraid to ask for help.

3. Start maintaining a healthy work-life balance from the outset. It can be very easy to put $100 \%$ of your time and effort into your work, especially when you are highly motivated and passionate about the subject. Spending time outside your job can stimulate new ideas that can improve your work and lower stress.

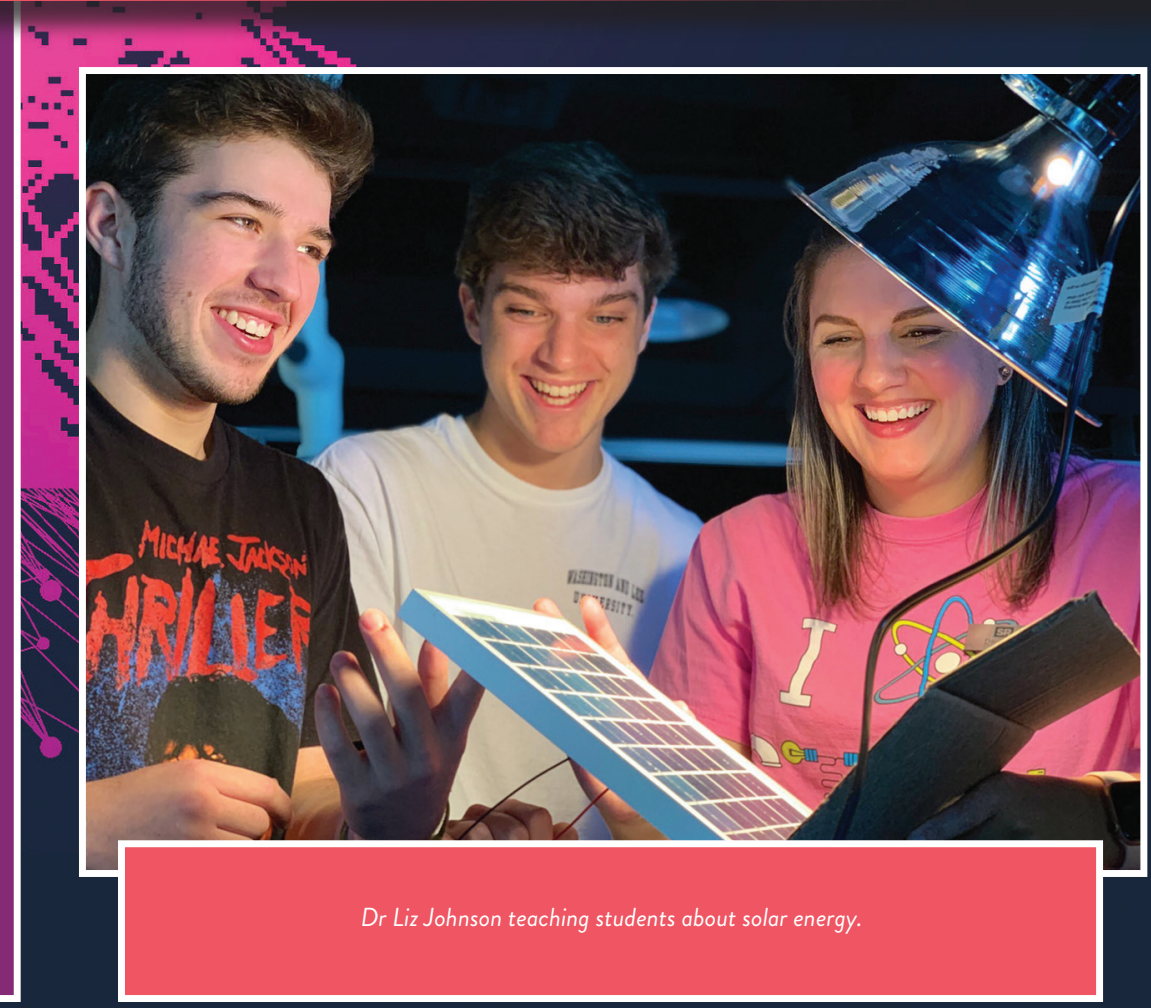

